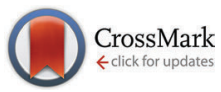

Cite this: Phys. Chem. Chem. Phys., 2016, 18, 32992

Received 28th October 2016 Accepted 15th November 2016 DOI: $10.1039 / c 6 c p 07386 g$

www.rsc.org/pccp

\title{
Impact of the molecular structure and adsorption mode of $D-\pi-A$ dye sensitizers with a pyridyl group in dye-sensitized solar cells on the adsorption equilibrium constant for dye-adsorption on $\mathrm{TiO}_{2}$ surface
}

\author{
Yousuke Ooyama,* Naoya Yamaguchi, Joji Ohshita and Yutaka Harima*
}

\begin{abstract}
$\mathrm{D}-\pi-\mathrm{A}$ dyes $\mathrm{NI}-\mathbf{4}$ bearing a pyridyl group, YNI-1 bearing two pyridyl groups and YNI-2 bearing two thienylpyridyl groups as the anchoring group on the $\mathrm{TiO}_{2}$ surface have been developed as dye sensitizers for dye-sensitized solar cells (DSSCs), where NI-4 and YNI-2 can adsorb onto the $\mathrm{TiO}_{2}$ electrode through the formation of the coordinate bond between the pyridyl group of the dye and the Lewis acid site (exposed $\mathrm{Ti}^{n+}$ cations) on the $\mathrm{TiO}_{2}$ surface, but $\mathrm{YNI}-\mathbf{1}$ is predominantly adsorbed on the $\mathrm{TiO}_{2}$ electrode through the formation of the hydrogen bond between the pyridyl group of the dye and the Brønsted acid sites (surface-bound hydroxyl groups, $\mathrm{Ti}-\mathrm{OH}$ ) on the $\mathrm{TiO}_{2}$ surface. The difference in the dye-adsorption mode among the three dyes on the $\mathrm{TiO}_{2}$ surface has been investigated from the adsorption equilibrium constant $\left(K_{\mathrm{ad}}\right)$ based on the Langmuir adsorption isotherms. It was found that the $K_{\text {ad }}$ values of YNI-1 and $\mathbf{Y N I - 2}$ are higher than that of NI-4, and more interestingly, the $K_{\text {ad }}$ value of YNI-2 is higher than that of YNI-1. This work demonstrates that that for the $D-\pi-A$ dye sensitizers with the pyridyl group as the anchoring group to the $\mathrm{TiO}_{2}$ surface the number of pyridyl groups and the dyeadsorption mode on the $\mathrm{TiO}_{2}$ electrode as well as the molecular structure of the dye sensitizer affect the $K_{\text {ad }}$ value for the adsorption of the dye to the $\mathrm{TiO}_{2}$ electrode, that is, resulting in a difference in the $K_{\text {ad }}$ value among the $D-\pi-A$ dye sensitizers $\mathrm{NI}-4$, YNI-1 and $\mathrm{YNI}-2$
\end{abstract}

\section{Introduction}

Twenty-five years have passed since Grätzel and co-workers developed high-performance dye-sensitized solar cells (DSSCs) employing a Ru-complex dye-adsorbed $\mathrm{TiO}_{2}$ electrode in 1991, ${ }^{1}$ but DSSCs are still receiving considerable attention as one of the most promising new renewable photovoltaic cells from chemists, physicists, and engineers. ${ }^{2-9}$ To further improve the photovoltaic performances of DSSCs, much effort has been made toward the development of various types of organic dye sensitizers bearing a carboxyl group, ${ }^{10-16}$ aldehyde, ${ }^{17,18}$ nitro group, ${ }^{19}$ 2-(1,1-dicyanomethylene)rhodanine, ${ }^{20}$ pyridine, ${ }^{21-24}$ or 8-hydroxylquinoline ${ }^{25}$ as the electron-withdrawing anchoring group that possesses high dye loading and high surface coverage of the $\mathrm{TiO}_{2}$ electrode, leading to good light-harvesting features over the wide spectral region of sunlight and high electroninjection efficiencies from the photoexcited dyes to the conduction

Department of Applied Chemistry, Graduate School of Engineering, Hiroshima University, Higashi-Hiroshima 739-8527, Japan.

E-mail: yooyama@hiroshima-u.ac.jp; Fax: +81 82-424-5494 band (CB) of the $\mathrm{TiO}_{2}$ electrode. In particular, many kinds of donor-acceptor $\pi$-conjugated (D- $\pi-\mathrm{A})$ dyes bearing a carboxyl group have been designed and developed as one of the most promising classes of organic dye sensitizers because of their strong photoabsorption properties originating from the intramolecular charge transfer (ICT) excitation from the donor to the acceptor (carboxyl group) moiety in the D- $\pi-A$ structures. ${ }^{3,4,6}$ The $\mathrm{D}-\pi-\mathrm{A}$ dye sensitizers bearing a carboxyl group are adsorbed on the $\mathrm{TiO}_{2}$ electrode through the bidentate bridging linkage between the carboxyl group of the dye and Brønsted acid sites (surface-bound hydroxyl groups, Ti-OH) on the $\mathrm{TiO}_{2}$ surface (Fig. 1a and 2a; NI-2 ${ }^{21 b}$ as a typical D- $\pi-\mathrm{A}$ dye sensitizer bearing a carboxyl group). Thus, the photoabsorption properties associated with the ICT excitation of the $\mathrm{D}-\pi-\mathrm{A}$ dye can lead to efficient electron transfer from the photoexcited dye through the carboxyl group to the $\mathrm{CB}$ of the $\mathrm{TiO}_{2}$ electrode. As the result, the DSSCs based on the $\mathrm{D}-\pi-\mathrm{A}$ porphyrin dye sensitizers bearing a carboxyl group have achieved a solar energy-to-electricity conversion yield $(\eta)$ of up to $13 \% .{ }^{11 c, d}$

On the other hand, we have designed and developed $\mathrm{D}-\pi-\mathrm{A}$ dye sensitizers bearing a pyridyl group as the anchoring group 
(a)

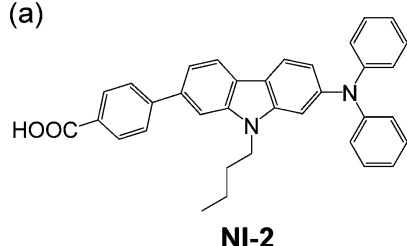

(c)

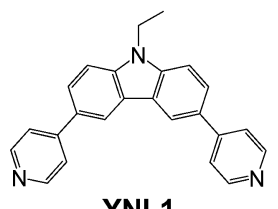

YNI-1 (b)



(d)

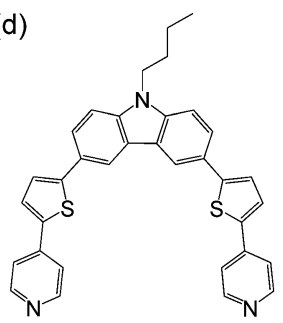

YNI-2

Fig. 1 Chemical structures of $D-\pi-A$ dye sensitizers: (a) NI-2 bearing a carboxyl group, (b) NI-4 bearing a pyridyl group, (c) YNI-1 bearing two pyridyl groups and (d) YNI-2 bearing two thienylpyridyl groups.

(a)

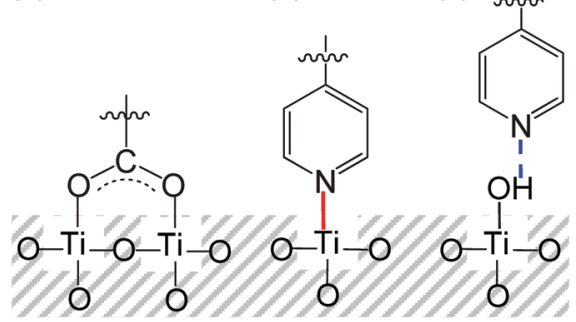

Fig. 2 Possible binding modes of the carboxyl group and pyridyl group on the $\mathrm{TiO}_{2}$ surface. (a) A bidentate bridging linkage for the carboxyl group, (b) a coordination bond for the pyridyl group and (c) a hydrogen bond for the pyridyl group.

to the $\mathrm{TiO}_{2}$ surface so far. ${ }^{21}$ It was found that the D- $\pi$-A dye sensitizer NI-4 bearing a pyridyl group is predominantly adsorbed on the $\mathrm{TiO}_{2}$ electrode through the coordination bond between the pyridyl group of the dye and the Lewis acid site (exposed $\mathrm{Ti}^{n+}$ cations) on the $\mathrm{TiO}_{2}$ surface (Fig. $1 \mathrm{~b}$ and $2 \mathrm{~b}$ ). ${ }^{21 b, c}$ The difference in the dye-adsorption mode between NI-2 and NI-4 on the $\mathrm{TiO}_{2}$ surface has been investigated from the Langmuir adsorption isotherms, and analysis of the Langmuir plots showed that the saturated dye-adsorption amounts $\left(C_{0}\right)$ of NI-2 and NI-4 on the $\mathrm{TiO}_{2}$ electrode are similar to each other. On the other hand, the adsorption equilibrium constant $\left(K_{\mathrm{ad}}\right)$ of NI-4 is smaller than that of NI-2, that is, the fact indicates that the pyridyl group is a relatively weak anchoring ability to the $\mathrm{TiO}_{2}$ surface compared with the carboxyl group. ${ }^{22 a}$ Interestingly, the photovoltaic performance of DSSCs based on NI-4 is higher than that based on NI-2. Thus, it was revealed that the $\mathrm{D}-\pi-\mathrm{A}$ dye sensitizers bearing a pyridyl group can inject electrons efficiently from the pyridyl group to the $\mathrm{CB}$ of the $\mathrm{TiO}_{2}$ electrode through the coordination bond, compared to the bidentate bridging linkages of the $\mathrm{D}-\pi-\mathrm{A}$ dye sensitizers bearing a carboxyl group. Consequently, we demonstrated that the pyridyl group is a promising candidate as not only an electron-withdrawing anchoring group but also an electron-injecting group for $\mathrm{D}-\pi-\mathrm{A}$ dye sensitizers. More interestingly, we found that the $\mathrm{D}-\pi-\mathrm{A}$ dye sensitizer YNI-2 with two thienylpyridyl groups can adsorb onto the $\mathrm{TiO}_{2}$ electrode through the formation of the coordinate bond between the pyridyl group of the dye and the Lewis acid site on the $\mathrm{TiO}_{2}$ surface (Fig. $1 \mathrm{~d}$ and $2 \mathrm{~b}$ ), but the $\mathrm{D}-\pi-\mathrm{A}$ dye sensitizer YNI-1 with two pyridyl groups is predominantly adsorbed on the $\mathrm{TiO}_{2}$ electrode through the formation of the hydrogen bond between the pyridyl group of the dye and the Brønsted acid sites on the $\mathrm{TiO}_{2}$ surface (Fig. 1c and 2c). ${ }^{21 d}$ The photovoltaic performance of DSSCs based on YNI-2 is higher than that based on YNI-1. Consequently, our previous work demonstrated that the higher photovoltaic performance of YNI-2 is attributed to not only the red-shift and broadening of the photoabsorption band originating from the ICT and the stable oxidized state of the dye, but also to efficient electron injection by the formation of the coordinate bond at Lewis acid sites on the $\mathrm{TiO}_{2}$ surface. Recently, some researchers have reported high-performance DSSCs based on porphyrin dyes or D- $\pi-\mathrm{A}$ dyes bearing pyridyl groups $;^{22-24}$ as a result, the $\eta$ value reached up to $8.2 \%$. $^{24 e}$ However, a comprehensive understanding of the difference in the dye-adsorption modes among the dye sensitizers bearing the pyridyl group is still lacking.

Thus, in this work, to gain insight into the molecular structure and the adsorption mode of $\mathrm{D}-\pi-\mathrm{A}$ dye sensitizers with a pyridyl group on the $\mathrm{TiO}_{2}$ surface, the difference in the dye-adsorption mode among NI-4, YNI-1 and YNI-2 on the $\mathrm{TiO}_{2}$ surface has been investigated from the $K_{\mathrm{ad}}$ value based on the Langmuir adsorption isotherms. The Langmuir plots showed that the $C_{0}$ value of NI-4 on the $\mathrm{TiO}_{2}$ electrode is slightly larger than those of YNI-1 and YNI-2, but the $C_{0}$ values of YNI-1 and YNI-2 are similar to each other. Moreover, it was found that the $K_{\text {ad }}$ values of YNI-1 and YNI-2 are higher than that of NI-4, and more interestingly, the $K_{\mathrm{ad}}$ value of YNI-2 is higher than that of YNI-1. Here, we report that the impacts of the molecular structure and adsorption mode of $\mathrm{D}-\pi-\mathrm{A}$ dye sensitizers with a pyridyl group for DSSCs on the adsorption equilibrium constant for dye-adsorption to the $\mathrm{TiO}_{2}$ surface.

\section{Results and discussion}

A $9 \mu \mathrm{m}\left(1.5 \mathrm{~cm}^{2}\right)$ thick $\mathrm{TiO}_{2}$ electrode was immersed into THF solutions containing various concentrations $(0.02,0.04,0.06$, $0.08,0.1,0.2,0.5,1.0$ or $1.0 \mathrm{mM}$ ) of NI-4, YNI-1 or YNI-2 for dye-adsorption on the $\mathrm{TiO}_{2}$ surface. In all cases, dye-adsorption was performed for $24 \mathrm{~h}$ in an incubator kept at $25{ }^{\circ} \mathrm{C}$. The dye-adsorbed $\mathrm{TiO}_{2}$ electrode was immersed in a $1 \mathrm{M}$ THFDMSO-NaOH aq. mixed solvent $(5: 4: 1)$ to desorb the dye molecules, that is, the adsorption amount of NI-4, YNI-1 and YNI-2 was determined by recording the photoabsorption spectra of the solutions on a spectrophotometer. Consequently, the amount $\left(C_{\mathrm{ad}}\right)$ of dyes adsorbed on the $\mathrm{TiO}_{2}$ electrode is expressed by the number of dye molecules per unit area of the $\mathrm{TiO}_{2}$ surface calculated using a specific surface area of $830 \mathrm{~cm}^{2} \mathrm{mg}^{-1}$. The $C_{\mathrm{ad}}{ }^{-1}$ versus $[\mathrm{Dye}]^{-1}$ (the concentration of the dye solution) plots 
(a)

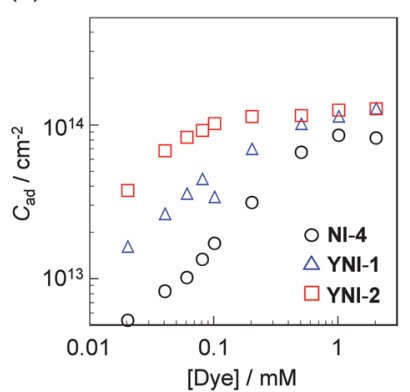

(b)

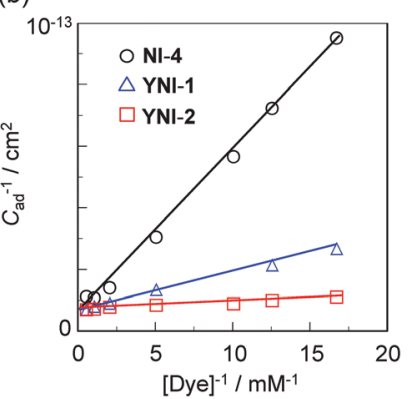

Fig. 3 (a) Adsorption isotherms of NI-4, YNI-1 and YN-2 on the $\mathrm{TiO}_{2}$ electrode. (b) Double-reciprocal Langmuir plots of the data shown in (a). Best fitting lines were obtained from the linear-least-squares method.

in the double-logarithmic representation depicts the adsorption isotherms for NI-4, YNI-1 and YNI-2 adsorbed on the $\mathrm{TiO}_{2}$ surface (Fig. 3a). The adsorption isotherms showed that for the three dyes the adsorption amount of dye molecules adsorbed on the $\mathrm{TiO}_{2}$ electrode increased with the increasing concentration of the dye solution. However, it is seen clearly from the adsorption isotherms that the adsorption trends of the three dyes differ greatly from each other, reflecting the differences in the molecular structure and the adsorption mode among NI-4, YNI-1 and YNI-2. Thus, to investigate the difference in the adsorption trends among the three dyes from the Langmuir plots, the three adsorption isotherms were analyzed by using the following equation:

$$
C_{\mathrm{ad}}{ }^{-1}=\left(K_{\mathrm{ad}} C_{0}\right)^{-1}[\mathrm{Dye}]^{-1}+C_{0}^{-1}
$$

derived from a Langmuir isotherm: ${ }^{26}$

$$
C_{\mathrm{ad}} / C_{0}=K_{\mathrm{ad}}[\text { Dye }] /\left(1+K_{\mathrm{ad}}[\text { Dye }]\right)
$$

where $C_{\mathrm{ad}}, C_{0}, K_{\mathrm{ad}}$, and [Dye] denote the adsorption amount of dye, adsorption amount of dye at saturation, adsorption equilibrium constant, and equilibrium concentration of dye, respectively. Fig. 3b $\left(C_{\mathrm{ad}}{ }^{-1}\right.$ versus $[\text { Dye }]^{-1}$ plots $)$ represents the Langmuir plots obtained from the data of Fig. 3a for NI-4, YNI-1 and YNI-2. The plots fit straight lines very well, demonstrating that adsorption of the three dyes on the $\mathrm{TiO}_{2}$ surface follows a Langmuir isotherm. The Langmuir isotherm holds when the following conditions are valid: monolayer adsorption, equivalent adsorption site, and negligible interaction between the adsorbed molecules. Thus, the $C_{0}$ and $K_{\mathrm{ad}}$ values were obtained by the linear least squares method as $1.7 \times 10^{14} \mathrm{~cm}^{-2}$ and $1.1 \times 10^{3} \mathrm{M}^{-1}$ for NI-4, $1.4 \times 10^{14} \mathrm{~cm}^{-2}$ and $6.1 \times 10^{3} \mathrm{M}^{-1}$ for YNI-1, and $1.3 \times$ $10^{14} \mathrm{~cm}^{-2}$ and $33.1 \times 10^{3} \mathrm{M}^{-1}$ for YNI-2, respectively. The adsorption parameters of the three dyes from the Langmuir isotherms are summarized in Table 1, together with correlation coefficients $(R)$ in the linear regression analysis. It was found that the $C_{0}$ value of NI-4 on the $\mathrm{TiO}_{2}$ electrode is slightly larger than those of YNI-1 and YNI-2, but the $K_{\mathrm{ad}}$ values of YNI-1 and YNI-2 are higher than that of NI-4. This result indicates that a rod-shaped $\mathrm{D}-\pi-\mathrm{A}$ dye sensitizer with a pyridyl group such as NI-4 can effectively cover the $\mathrm{TiO}_{2}$ surface compared with relatively bulky bifurcation-shaped $\mathrm{D}-\pi-\mathrm{A}$ dye sensitizers with

Table 1 A adsorption parameters of NI-4, YNI-1 and YNI-2 obtained from Langmuir isotherms

\begin{tabular}{lcrl}
\hline Dye & $C_{0} / \mathrm{cm}^{-2}$ & \multicolumn{1}{c}{$K_{\mathrm{ad}} / \mathrm{M}^{-1}$} & $R^{a}$ \\
\hline NI-4 & $1.7 \times 10^{14}$ & $1.1 \times 10^{3}$ & 0.9969 \\
YNI-1 & $1.4 \times 10^{14}$ & $6.1 \times 10^{3}$ & 0.9980 \\
YNI-2 & $1.3 \times 10^{14}$ & $33.1 \times 10^{3}$ & 0.9653 \\
${ }^{a} R$ denotes a correlation coefficient. & &
\end{tabular}

two pyridyl groups such as YNI-1 and YNI-2, on the other hand, the bifurcation-shaped structure with the two pyridyl groups can strongly adsorb on the $\mathrm{TiO}_{2}$ surface compared with the rod-shaped $\mathrm{D}-\pi-\mathrm{A}$ structure with a pyridyl group. Moreover, it is worth noting here that the $C_{0}$ values of YNI-1 and YNI-2 are similar to each other, but the $K_{\text {ad }}$ value of YNI-2 is higher than that of YNI-1. Thus, these results indicate that the adsorption ability of YNI-2 onto the $\mathrm{TiO}_{2}$ surface is superior to that of YNI-1. The fact may be attributed to the difference in binding modes between the two dyes on the $\mathrm{TiO}_{2}$ electrode.

Therefore, to gain insight into the impact of the molecular structure and the adsorption mode of $\mathrm{D}-\pi-\mathrm{A}$ dye sensitizers with a pyridyl group on the adsorption equilibrium constant for dye-adsorption to the $\mathrm{TiO}_{2}$ surface, we evaluated the photovoltaic performance of DSSCs based on the co-adsorbed $\mathrm{TiO}_{2}$ electrode with the dye YNI-1 or YNI-2 and chenodeoxycholic acid (CDCA) capable of adsorbing at the Brønsted acid sites on the $\mathrm{TiO}_{2}$ electrode. For co-adsorption the concentration of CDCA was changed, with that of YNI-1 or YNI-2 kept constant at $0.1 \mathrm{mM}$, where $0.1 \mathrm{mM}$ dye and $1.0 \mathrm{mM}$ CDCA solution, and $0.1 \mathrm{mM}$ dye and $5.0 \mathrm{mM}$ CDCA solution were used. The photocurrent-voltage $(I-V)$ characteristics of DSSCs based on the co-adsorbed $\mathrm{TiO}_{2}$ electrode with the dye YNI-1 or YNI-2 and CDCA were measured under simulated solar light (AM 1.5, $100 \mathrm{~mW} \mathrm{~cm}^{-2}$ ) and the $I-V$ curves are shown in Fig. 4. The photovoltaic performances of the DSSCs are summarized in Table 2. We expected that for the co-adsorption of YNI-1 and CDCA the adsorption of YNI-1 onto the $\mathrm{TiO}_{2}$ electrode may compete with that of CDCA because YNI-1 and CDCA adsorb on the same acid sites (Brønsted acid sites), leading to a decrease in the short-circuit photocurrent density $\left(J_{\mathrm{sc}}\right)$ and the solar energy-to-electricity conversion yield $(\eta)$ with the increase in the concentration of CDCA. On the other hand, YNI-2 and (a)

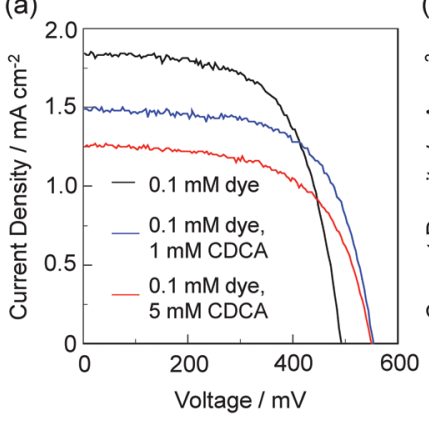

(b)

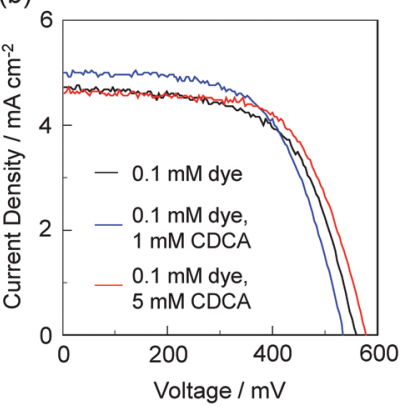

Fig. 4 I-V curves of DSSCs based on (a) YNI-1 and (b) YNI-2 with and without CDCA as a co-adsorbent. 
Table 2 DSSC performance parameters of YNI-1 and YNI-2

\begin{tabular}{llllll}
\hline Dye & CDCA $/ \mathrm{mM}$ & $J_{\mathrm{sc}}{ }^{d} / \mathrm{mA} \mathrm{cm}^{-2}$ & $V_{\mathrm{oc}}{ }^{d} / \mathrm{mV}$ & $\mathrm{ff}^{d}$ & $\eta^{d}(\%)$ \\
\hline YNI-1 & $0^{a}$ & 1.84 & 492 & 0.63 & 0.57 \\
& $1^{b}$ & 1.49 & 552 & 0.51 & 0.42 \\
& $5^{c}$ & 1.25 & 548 & 0.61 & 0.42 \\
YNI-2 & $0^{a}$ & 4.72 & 556 & 0.61 & 1.60 \\
& $1^{b}$ & 5.00 & 532 & 0.60 & 1.60 \\
& $5^{c}$ & 4.60 & 576 & 0.65 & 1.72
\end{tabular}

${ }^{a}$ A $9 \mu \mathrm{m}$ thick $\mathrm{TiO}_{2}$ electrode was used. $0.1 \mathrm{mM}$ dye solution in acetonitrile. ${ }^{b}$ A $9 \mu \mathrm{m}$ thick $\mathrm{TiO}_{2}$ electrode was used. $0.1 \mathrm{mM}$ dye and $1 \mathrm{mM}$ CDCA solution. ${ }^{c}$ A $9 \mu \mathrm{m}$ thick $\mathrm{TiO}_{2}$ electrode was used. $0.1 \mathrm{mM}$ dye and $5 \mathrm{mM}$ CDCA solution. ${ }^{d}$ Under simulated solar light (AM 1.5, $100 \mathrm{~mW} \mathrm{~cm}^{-2}$ ).

CDCA adsorb independently on the $\mathrm{TiO}_{2}$ surface because YNI-2 and CDCA adsorb at different acid sites, the Lewis acid sites and Brønsted acid sites on the $\mathrm{TiO}_{2}$ surface, respectively, and thus regardless of the concentration of CDCA the co-adsorption of YNI-2 and CDCA has little influence on the $J_{\mathrm{sc}}$ value and the $\eta$ value. As is shown in Table 2, for the co-adsorption of YNI-1 and CDCA, with the increase in the concentration of CDCA, the $\eta$ value as well as the $J_{\mathrm{sc}}$ value of DSSCs based on the co-adsorbed $\mathrm{TiO}_{2}$ electrode with YNI-1 and CDCA decreases. Therefore, the adsorption of YNI-1 onto the $\mathrm{TiO}_{2}$ surface may compete with that of CDCA, that is, by increasing the concentration of CDCA the adsorption amount of YNI-1 may decrease, being accompanied by an increase in that of CDCA. This may be explained by the fact that YNI-1 and CDCA adsorb on the same acid sites (Brønsted acid sites), and thus the increase in the concentration of CDCA leads to a decrease in the adsorption amount of YNI-1 by the competitive adsorption of CDCA. On the other hand, for the co-adsorption of YNI-2 and CDCA there are no appreciable changes in the $J_{\mathrm{sc}}$ value and the $\eta$ value with the increase in the concentration of CDCA, suggesting that YNI-2 and CDCA adsorb independently on the $\mathrm{TiO}_{2}$ surface because YNI-2 and CDCA adsorb on different acid sites (Lewis acid sites for YNI-2 and Brønsted acid sites for CDCA, respectively). Therefore, the increase in the concentration of CDCA does not cause a decrease in the adsorption amount of YNI-2 without the competitive adsorption of CDCA, consistent with our previous result for NI-4. ${ }^{22 a}$ Consequently, these results indicate that the co-adsorption of YNI-1 and CDCA causes the competitive adsorption between the dye and CDCA, leading to a decrease in the amount of the dye adsorbed on the $\mathrm{TiO}_{2}$ electrode, thus resulting in a reduction of the photovoltaic performance of the DSSCs, but for the co-adsorption of YNI-2 and CDCA the competitive adsorption was not observed and the thus the co-adsorption has little influence on the photovoltaic performance of the DSSCs.

On the basis of the Langmuir isotherms and the co-adsorption of the dye YNI-1 or YNI-2 and CDCA onto the $\mathrm{TiO}_{2}$ electrode, it is concluded that the high $K_{\mathrm{ad}}$ value of YNI-2 relative to that of YNI-1 is attributed to the reasonable angle between two thienylpyridine moieties (based on MO calculations (MOPAC and AM1 method), ${ }^{21 c, d}$ it is defined as the angle between the two pyridines as the corner N2 for the nitrogen atom (N2) of carbazole and the nitrogen atoms ( $\mathrm{N} 1$ and $\mathrm{N} 3$ ) of the two pyridyl groups, that is ca. $90^{\circ}$ for YNI-1 and $c a .67^{\circ}$ for YNI-2) as well as the accumulated electron density on the nitrogen atom of the pyridyl groups due to a large planar $\pi$-conjugated system extending from the electron donor moiety to the electron acceptor moiety by the introduction of a thiophene unit, leading to the construction of molecular structures capable of forming strong coordinate bonds between the two pyridyl groups of dyes and the Lewis acid sites on the $\mathrm{TiO}_{2}$ surface. On the other hand, YNI-1 is constructed with the rigid $\mathrm{D}-\pi-\mathrm{A}$ structure due to the pyridyl groups directly bound to the carbazole skeleton. Therefore, it is reasonable to presume that the rigid molecular structure of YNI-1 makes it difficult to form the coordination bond between the pyridyl group of the dye and the Lewis acid site on the $\mathrm{TiO}_{2}$ surface, but instead prefers to form the hydrogen bond between the pyridyl group of the dye and the flexible surface-bound hydroxyl groups (Brønsted acid sites) on the $\mathrm{TiO}_{2}$ surface, resulting in a relatively low $K_{\text {ad }}$ value. Consequently, this work demonstrates that for the $\mathrm{D}-\pi-\mathrm{A}$ dye sensitizers with the pyridyl group as the anchoring group to the $\mathrm{TiO}_{2}$ surface, the number of pyridyl groups and the dyeadsorption mode on the $\mathrm{TiO}_{2}$ electrode as well as the molecular structure of the dye sensitizer affect the $K_{\mathrm{ad}}$ value for the adsorption of the dye to the $\mathrm{TiO}_{2}$ electrode, that is, resulting in a difference in the $K_{\mathrm{ad}}$ value among the $\mathrm{D}-\pi-\mathrm{A}$ dye sensitizers NI-4, YNI-1 and YNI-2.

\section{Conclusions}

The difference in the dye-adsorption modes among $\mathrm{D}-\pi-\mathrm{A}$ dye sensitizers NI-4 with a pyridyl group, YNI-1 with two pyridyl groups and YNI-2 with two thienylpyridyl groups on the $\mathrm{TiO}_{2}$ electrode has been investigated from the adsorption equilibrium constant $\left(K_{\mathrm{ad}}\right)$ based on the Langmuir adsorption isotherms. It was found that a rod-shaped $\mathrm{D}-\pi-\mathrm{A}$ dye sensitizer with a pyridyl group such as NI-4 can effectively cover the $\mathrm{TiO}_{2}$ surface compared with relatively bulky bifurcation-shaped $\mathrm{D}-\pi-\mathrm{A}$ dye sensitizer with two pyridyl groups such as YNI-1 and YNI-2; on the other hand, the bifurcation-shaped structure with the two pyridyl groups can strongly adsorb on the $\mathrm{TiO}_{2}$ surface compared with the rod-shaped $\mathrm{D}-\pi-\mathrm{A}$ structure with a pyridyl group. More interestingly, the $K_{\mathrm{ad}}$ value of YNI-2 is higher than that of YNI-1, which indicates that the adsorption ability of YNI-2 onto the $\mathrm{TiO}_{2}$ surface is superior to that of YNI-1. Thus, it was revealed that the number of pyridyl groups and the dye-adsorption mode on the $\mathrm{TiO}_{2}$ electrode as well as the molecular structure of the dye sensitizer affect the $K_{\text {ad }}$ value for the adsorption of the dye to the $\mathrm{TiO}_{2}$ electrode, resulting in a difference in the $K_{\mathrm{ad}}$ value among the $D-\pi-A$ dye sensitizers NI-4, YNI-1 and YNI-2. Consequently, this work provides useful knowledge of the molecular design of $\mathrm{D}-\pi-\mathrm{A}$ dye sensitizers bearing a pyridyl group capable of controlling the dye-adsorption mode on the $\mathrm{TiO}_{2}$ electrode for DSSCs.

\section{Experimental}

Preparation of the dye-adsorbed $\mathrm{TiO}_{2}$ electrode and DSSCs

The $\mathrm{TiO}_{2}$ paste (JGC Catalysts and Chemicals Ltd, PST-18NR) was deposited on a fluorine-doped-tin-oxide (FTO) substrate by 
doctor-blading, and sintered for $50 \mathrm{~min}$ at $450{ }^{\circ} \mathrm{C}$. The $9 \mu \mathrm{m}$ $\left(1.5 \mathrm{~cm}^{2}\right)$ thick $\mathrm{TiO}_{2}$ electrode was immersed into 0.02, 0.04, $0.06,0.08,0.1,0.2,0.5,1.0$ or $1.0 \mathrm{mM}$ dye solution in THF for $24 \mathrm{~h}$ in an incubator kept at $25{ }^{\circ} \mathrm{C}$. For the co-adsorption of the dye and chenodeoxycholic acid (CDCA), $0.1 \mathrm{mM}$ dye and 1.0 $\mathrm{mM}$ CDCA solution, and $0.1 \mathrm{mM}$ dye and 5.0 mM CDCA solution were used. BET surface areas of the $\mathrm{TiO}_{2}$ particles were $830 \mathrm{~cm}^{2} \mathrm{mg}^{-1}$. Consequently, the total area for $1 \mathrm{~cm}^{2}$ geometric area of the electrode was $c a .1577 \mathrm{~cm}^{2}$ for $9 \mu \mathrm{m}$ thick $\mathrm{TiO}_{2}$ electrode. The dye-coated electrode was immersed in a mixed solvent of THF-DMSO-NaOH aq. $1 \mathrm{M}(5: 4: 1)$, which was used to determine the amount of dye molecules adsorbed onto the electrode by measuring the absorbance. The quantification of dye was made based on the molar extinction coefficient for $\lambda_{\max }^{\mathrm{abs}}$ of dye in the above solution. Photoabsorption spectra were observed with a Shimadzu UV-3150 spectrophotometer.

The DSSCs were fabricated by using the dye-adsorbed $\mathrm{TiO}_{2}$ electrode $\left(0.5 \times 0.5 \mathrm{~cm}^{2}\right.$ in photoactive area), Pt-coated glass as a counter electrode, and a solution of $0.05 \mathrm{M}$ iodine, $0.1 \mathrm{M}$ lithium iodide, and $0.6 \mathrm{M}$ 1,2-dimethyl-3-propylimidazolium iodide in acetonitrile as the electrolyte. The photocurrentvoltage characteristics were measured using a potentiostat under a simulated solar light (AM 1.5, $100 \mathrm{~mW} \mathrm{~cm}^{-2}$ ).

\section{Acknowledgements}

This work was supported by Grants-in-Aid for Scientific Research (B) from the Japan Society for the Promotion of Science (JSPS) KAKENHI, Grant Number 15H03859, by the Matching Planner Program (MP27115659061) from Japan Science and Technology Agency (JST) and by the TEPCO Memorial Foundation.

\section{Notes and references}

1 B. O'Regan and M. Grätzel, Nature, 1991, 353, 737.

2 A. Mishra, M. K. R. Fischer and P. Bäuerle, Angew. Chem. Int. Ed., 2009, 48, 2474.

3 (a) Y. Ooyama and Y. Harima, Eur. J. Org. Chem., 2009, 2903; (b) Y. Ooyama and Y. Harima, ChemPhysChem, 2012, 13, 4032.

4 (a) Z. Ning and H. Tian, Chem. Commun., 2009, 5483; (b) Z. Ning, Y. Fu and H. Tian, Energy Environ. Sci., 2010, 3, 1170 .

5 A. Hagfeldt, G. Boschloo, L. Sun, L. Kloo and H. Pettersson, Chem. Rev., 2010, 110, 6595.

6 N. Manfredi, B. Cecconi and A. Abbotto, Eur. J. Org. Chem., 2014, 7069.

7 L. Zhang and J. M. Cole, ACS Appl. Mater. Interfaces, 2015, 7, 3427.

8 C.-P. Lee, R. Y.-Y. Lin, L.-Y. Lin, C.-T. Li, T.-C. Chu, S.-S. Sun, J. T. Lin and K.-C. Ho, RSC Adv., 2015, 5, 23810.

9 B. Pashaei, H. Shahroosvand, M. Graetzel and M. K. Nazeeruddin, Chem. Rev., 2016, 116, 9485.
10 (a) H. Imahori, T. Umeyama and S. Ito, Acc. Chem. Res., 2009, 42, 1809; (b) L.-L. Li and E. W.-G. Diau, Chem. Soc. Rev., 2013, 42, 291; (c) K. Ladomenou, T. N. Kitsopoulos, G. D. Sharma and A. G. Coutsolelos, RSC Adv., 2014, 4, 21379; (d) T. Higashino and H. Imahori, Dalton Trans., 2015, 44, 448. 11 (a) T. Bessho, S. M. Zakeeruddin, C.-Y. Yeh, E. W.-G. Diau and M. Grätzel, Angew. Chem. Int. Ed., 2010, 49, 6646; (b) A. Yella, H.-W. Lee, H. N. Tsao, C. Yi, A. K. Chandiran, M. K. Nazeeruddin, E. W.-G. Diau, C.-Y. Yeh, S. M. Zakeeruddin and M. Grätzel, Science, 2011, 334, 629; (c) S. Mathew, A. Yella, P. Gao, R. Humphry-Baker, B. F. E. Curchod, N. Ashari-Astani, I. Tavernelli, U. Rothlisberger, K. Nazeeruddin and M. Grätzel, Nat. Chem., 2014, 6, 242; (d) A. Yella, C.-L. Mai, S. M. Zakeeruddin, S.-N. Chang, C.-H. Hsieh, C.-Y. Yeh and M. Grätzel, Angew. Chem. Int. Ed., 2014, 53, 2973; (e) T. Higashino, Y. Fujimori, K. Sugiura, Y. Tsuji, S. Ito and H. Imahori, Angew. Chem. Int. Ed., 2015, 54, 9052; $(f)$ J. P. Hill, Angew. Chem. Int. Ed., 2016, 55, 2976; (g) F. Lodermeyer, R. D. Costa, J. Malig, N. Jux and D. M. Guldi, Chem. Eur. J., 2016, 22, 7851; (h) G. Copley, D. Hwang, D. Kim and A. Osuka, Angew. Chem. Int. Ed., 2016, 55, 10287. 12 (a) T. Zhang, X. Qian, P. Zhang, Y.-Z. Zhu and J.-Y. Zheng, Chem. Commun., 2015, 51, 3782; (b) Y. Xie, Y. Tang, W. Wu, Y. Wang, J. Liu, X. Li, H. Tian and W.-H. Zhu, J. Am. Chem. Soc., 2015, 137, 14055; (c) K. Sirithip, N. Prachumrak, R. Rattanawan, T. Keawin, T. Sudyoadsuk, S. Namuangruk, S. Jungsuttiwong and V. Promarak, Chem. Asian J., 2015, 10, 882; (d) S. Mathew, N. A. Astani, B. F. E. Curchod, J. H. Delcamp, M. Marszalek, J. Frey, U. Rothlisberger, M. K. Nazeeruddina and M. Grätzel, J. Mater. Chem. A, 2016, 4, 2332; (e) L. Zeininger, F. Lodermeyer, R. D. Costa, D. M. Guldi and A. Hirsch, Chem. Commun., 2016, 52, 8842; ( $f$ ) J. Luo, J. Zhang, K.-W. Huang, Q. Qi, S. Dong, J. Zhang, P. Wang and J. Wu, J. Mater. Chem. A, 2016, 4, 8428; $(g)$ C. Li, L. Luo, D. Wu, R. Jiang, J. Lan, R. Wang, L. Huang, S. Yang and J. You, J. Mater. Chem. A, 2016, 4, 11829; (h) Y.-C. Liu, H.-H. Chou, F.-Y. Ho, H.-J. Wei, T.-C. Wei and C.-Y. Yeh, J. Mater. Chem. A, 2016, 4, 11878.

13 (a) J.-J. Cid, J.-H. Yum, S.-R. Jang, M. K. Nazeeruddin, E. Martínez-Ferrero, E. Palomares, J. Ko, M. Grätzel and T. Torres, Angew. Chem. Int. Ed., 2007, 46, 8358; (b) M. Kimura, H. Nomoto, N. Masaki and S. Mori, Angew. Chem. Int. Ed., 2012, 51, 4371; (c) M.-E. Ragoussi, J.-J. Cid, J.-H. Yum, G. De La Torre, D. D. Censo, M. Grätzel, M. K. Nazeeruddin and T. Torres, Angew. Chem. Int. Ed., 2012, 51, 4375; (d) L. Yu, K. Fan, T. Duan, X. Chen, R. Li and T. Peng, ACS Sustainable Chem. Eng., 2014, 2, 718; (e) T. Ikeuchi, H. Nomoto, N. Masaki, M. J. Griffith, S. Mori and M. Kimura, Chem. Commun., 2014, 50, 1941; $(f)$ T. Ikeuchi, S. Agrawal, M. Ezoe, S. Mori and M. Kimura, Chem. Asian J., 2015, 10, 2347; $(g)$ L. Tejerina, M. V. Martínez-Díaz, M. K. Nazeeruddin and T. Torres, Chem. Eur. J., 2016, 22, 4369.

14 (a) X. Wang, J. Yang, H. Yu, F. Li, L. Fan, W. Sun, Y. Liu, Z. Y. Koh, J. Pan, W.-L. Yim, L. Yan and Q. Wang, Chem. Commun., 2014, 50, 3965; (b) S.-G. Li, K.-J. Jiang, 
J.-H. Huang, L.-M. Yang and Y.-L. Song, Chem. Commun., 2014, 50, 4309; (c) D. K. Panda, F. S. Goodson, S. Ray and S. Saha, Chem. Commun., 2014, 50, 5358; (d) K. Kakiage, Y. Aoyama, T. Yano, T. Otsuka, T. Kyomen, M. Unno and M. Hanaya, Chem. Commun., 2014, 50, 6379; (e) A. Amacher, C. Yi, J. Yang, M. P. Bircher, Y. Fu, M. Cascella, M. Grätzel, S. Decurtins and S.-X. Liu, Chem. Commun., 2014, 50, 6540; $(f)$ W.-I. Hung, Y.-Y. Liao, T.-H. Lee, Y.-C. Ting, J.-S. Ni, W.-S. Kao, J. T. Lin, T.-C. Wei and Y.-S. Yen, Chem. Commun., 2015, 51, 2152; (g) X. Li, Z. Zheng, W. Jiang, W. Wu, Z. Wang and H. Tian, Chem. Commun., 2015, 51, 3590; (h) K. Kakiage, Y. I. Aoyama, T. Yano, K. Oya, T. Kyomen and M. Hanaya, Chem. Commun., 2015, 51, 6315; (i) L. Yang, Z. Zheng, Y. Li, W. Wu, H. Tian and Z. Wang, Chem. Commun., 2015, 51, 4842; $(j)$ N. Shibayama, Y. Inoue, M. Abe, S. Kajiyama, H. Ozawa, H. Miura and H. Arakawa, Chem. Commun., 2015, 51, 12795; (k) K. Kakiage, Y. Aoyama, T. Yano, K. Oya, J. Fujisawa and M. Hanaya, Chem. Commun., 2015, 51, 15894.

15 (a) J.-S. Ni, Y.-C. Yen and J. T. Lin, Chem. Commun., 2015, 51, 17080; (b) Y.-D. Lin, B.-Y. Ke, Y. J. Chang, P.-T. Chou, K.-L. Liau, C.-Y. Liu and T. J. Chow, J. Mater. Chem. A, 2015, 3, 16831; (c) S. S. Soni, K. B. Fadadu, J. V. Vaghasiya, B. G. Solanki, K. K. Sonigara, A. Singh, D. Das and P. K. Iyer, J. Mater. Chem. A, 2015, 3, 21664; (d) X. Li, Y. Hu, I. Sanchez-Molina, Y. Zhou, F. Yu, S. A. Haque, W. Wu, J. Hua, H. Tian and N. Robertson, J. Mater. Chem. A, 2015, 3, 2173; (e) Y. Hu, A. Ivaturi, M. Planells, C. L. Boldrini, A. O. Biroli and N. Robertson, J. Mater. Chem. A, 2016, 4, 2509; $(f)$ H. Wu, L. Yang, Y. Li, M. Zhang, J. Zhang, Y. Guo and P. Wang, J. Mater. Chem. A, 2016, 4, 519; $(g)$ J. Wu, G. Li, L. Zhang, G. Zhou and Z.-S. Wang, J. Mater. Chem. A, 2016, 4, 3342; (h) J.-S. Ni, Y.-C. Yen and J. T. Lin, J. Mater. Chem. A, 2016, 4, 6553; (i) A. J. Huckaba, A. Yella, P. Brogdon, J. S. Murphy, M. K. Nazeeruddin, M. Grätzel and J. H. Delcamp, Chem. Commun., 2016, 52, 8424; $(j)$ T.-Y. Li, C. Su, S. B. Akula, W.-G. Sun, H.-M. Chien and W.-R. Li, Org. Lett., 2016, 18, 3386; (k) Y. Gao, X. Li, Y. Hu, Y. Fan, J. Yuan, N. Robertson, J. Hua and S. R. Marder, J. Mater. Chem. A, 2016, 4, 12865.

16 (a) Z. Yao, M. Zhang, H. Wu, L. Yang, R. Li and P. Wang, J. Am. Chem. Soc., 2015, 137, 3799; (b) N. Zhou, K. Prabakaran, B. Lee, S. H. Chang, B. Harutyunyan, P. Guo, M. R. Butler, A. Timalsina, M. J. Bedzyk, M. A. Ratner, S. Vegiraju, S. Yau, C.-G. Wu, R. P. H. Chang, A. Facchetti, M.-C. Chen and T. J. Marks, J. Am. Chem. Soc., 2015, 137, 4414; (c) Y.-S. Yen, J.-S. Ni, T.-Y. Lin, W.-I. Hung, J. T. Lin and M.-C. P. Yeh, Eur. J. Org. Chem., 2015, 7367; (d) H. Jiang, G. Ferrara, X. Zhang, K. Oniwa, A. Islam, L. Han, Y.-J. Sun, M. Bao, N. Asao, Y. Yamamoto and T. Jin, Chem. Eur. J., 2015, 21, 4065; (e) K. Matsumura, S. Yoshizaki, M. M. Maitani, Y. Wada, Y. Ogomi, S. Hayase, T. Kaiho, S. Fuse, H. Tanaka and T. Takahashi, Chem. Eur. J., 2015, 21, 9742; $(f)$ K. D. Seo, I. T. Choi and H. K. Kim, Chem. Eur. J., 2015, 21, 14804; (g) B. Liu, F. Giordano, K. Pei, J.-D. Decoppet, W.-H. Zhu, S. M. Zakeeruddin and M. Grätzel, Chem. Eur. J., 2015, 21, 18654; (h) Z. Yao, M. Zhang, R. Li,
L. Yang, Y. Qiao and P. Wang, Angew. Chem. Int. Ed., 2015, 54, 5994; (i) P. Brogdon, F. Giordano, G. A. Puneky, A. Dass, S. M. Zakeeruddin, M. K. Nazeeruddin, M. Grätzel, G. S. Tschumper and J. H. Delcamp, Chem. Eur. J., 2016, 22, 694; (j) S. Irie, S. Fuse, M. M. Maitani, Y. Wada, Y. Ogomi, S. Hayase, T. Kaiho, H. Masui, H. Tanaka and T. Takahashi, Chem. Eur. J., 2016, 22, 2507; (k) F.-L. Guo, Z.-Q. Li, X.-P. Liu, L. Zhou, F.-T. Kong, W.-C. Chen and S.-Y. Dai, Adv. Funct. Mater., 2016, 26, 5733.

17 J. Tang, S. Qu, J. Hu, W. Wu and J. Hua, Sol. Energy, 2012, 86, 2306.

18 Y. Ooyama, Y. Hagiwara, Y. Oda, T. Mizumo, Y. Harima and J. Ohshita, New J. Chem., 2013, 37, 2336.

19 J. Cong, X. Yang, J. Liu, J. Zhao, Y. Hao, Y. Wang and L. Sun, Chem. Commun., 2012, 48, 6663.

20 J. Mao, N. He, Z. Ning, Q. Zhang, F. Guo, L. Chen, W. Wu, J. Hua and H. Tian, Angew. Chem. Int. Ed., 2012, 51, 9873.

21 (a) Y. Ooyama, S. Inoue, R. Asada, G. Ito, K. Kushimoto, K. Komaguchi, I. Imae and Y. Harima, Eur. J. Org. Chem., 2010, 92; (b) Y. Ooyama, S. Inoue, T. Nagano, K. Kushimoto, J. Ohshita, I. Imae, K. Komaguchi and Y. Harima, Angew. Chem. Int. Ed., 2011, 50, 7429; (c) Y. Ooyama, T. Nagano, S. Inoue, I. Imae, K. Komaguchi, J. Ohshita and Y. Harima, Chem. - Eur. J., 2011, 17, 14837; (d) Y. Ooyama, N. Yamaguchi, I. Imae, K. Komaguchi, J. Ohshita and Y. Harima, Chem. Commun., 2013, 49, 2548; (e) Y. Ooyama, Y. Hagiwara, T. Mizumo, Y. Harima and J. Ohshita, New J. Chem., 2013, 37, 2479; $(f)$ Y. Ooyama, T. Sato, Y. Harima and J. Ohshita, J. Mater. Chem. A, 2014, 2, 3293; (g) Y. Ooyama, K. Uenaka and J. Ohshita, Eur. J. Org. Chem., 2015, 3713; (h) Y. Ooyama, K. Uenaka, T. Kamimura, S. Ozako, M. Kanda, T. Koide and F. Tani, RSC Adv., 2016, 6, 16150 .

22 (a) Y. Harima, T. Fujita, Y. Kano, I. Imae, K. Komaguchi, Y. Ooyama and J. Ohshita, J. Phys. Chem. C, 2013, 117, 16364; (b) N. Shibayama, H. Ozawa, M. Abe, Y. Ooyama and H. Arakawa, Chem. Commun., 2014, 50, 6398; (c) Y. Ooyama, K. Uenaka, T. Sato, N. Shibayama and J. Ohshita, RSC Adv., 2015, 5, 2531; (d) J. Ohshita, Y. Adachi, D. tanaka, M. Nakashima and Y. Ooyama, RSC Adv., 2015, 5, 36673; (e) Y. Harima, Y. Kano, T. Fujita, I. Imae, Y. Ooyama and J. Ohshita, RSC Adv., 2015, 5, 71387; $(f)$ Y. Adachi, Y. Ooyama, N. Shibayama and J. Ohshita, Dalton Trans., 2016, 45, 13817.

23 (a) D. Daphnomili, G. D. Sharma, S. Biswas, T. K. R. Justin and A. G. Goutsolelos, J. Photochem. Photobiol. A, 2013, 253, 88; (b) J. Lu, X. Xu, Z. Li, k. Cao, J. Cui, Y. Zhang, Y. Shen, Y. Li, J. Zhu, S. Dai, W. Chjen, Y. Cheng and M. Wang, Chem.-Asian J., 2013, 8, 956; (c) M.-D. Zhang, H.-X. Xie, X.-H. Ju, L. Qin, Q.-X. Yang, H.-G. Zheng and X.-F. Zhou, Phys. Chem. Chem. Phys., 2013, 15, 634-641; (d) D. Daphnomili, G. Landrou, P. Singh, A. Thomas, K. Yesudas, B. K. G. D. Sharma and A. G. Goutsolelos, RSC $A d v$. 2012, 2, 12899; (e) L. Wang, X. yang, S. Li, M. Cheng and L. Sun, $R S C A d v$. , 2013, 3, 13677; $(f)$ T. Sakurada, Y. Arai and H. Segawa, RSC Adv., 2014, 4, 13201; (g) J. Mao, 
D. Wang, S.-H. Liu, Y. Hang, Y. Xu, Q. Zhang, W. Wu, P.-T. Chou and J. Hua, Asian J. Org. Chem., 2014, 3, 153; (h) T. Ikeuchi, S. Agrawal, M. Ezoe, S. Mori and M. Kimura, Chem. Asian J., 2015, 10, 2347.

24 (a) C. Stangel, A. Bagaki, P. A. Angaridis, G. Charalambidis, G. D. Sharma and A. G. Coutsolelos, Inorg. Chem., 2014, 53, 11871; (b) M. N. K. P. Bolisetty, C.-T. Li, K. R. J. Thomas, G. B. Bodedla and K.-C. Ho, Tetrahedron, 2014, 70, 4203; (c) D. Franchi, M. Calamante, G. Reginato, L. Zani, M. Peruzzini, M. Taddei, F. F. de Biani, R. Basosi, A. Sinicropi, D. Colonna, A. Di Carlo and A. Mordin, Tetrahedron, 2014, 70, 6285; (d) E. V. Verbitskiy, E. M. Cheprakova, J. O. Subbotina, A. V. Schepochkin, P. A. Slepukhin, G. L. Rusinov, V. N. Charushin, O. N. Chupakhin, N. I. Makarova, A. V. Metelitsa and V. I. Minkin, Dyes Pigm., 2014, 100, 201; (e) C.-L. Mai, T. Moehl, C.-H. Hsieh, J.-D. Décoppet, S. M. Zakeeruddin, M. Grätzel and C.-Y. Yeh, ACS Appl. Mater. Interfaces, 2015, 7, 14975; $(f)$ H. Jia, K. Shen, X. I. Ju, M. Zhanga and H. Zheng, New J. Chem., 2016, 40, 2799; (g) P. A. Angaridis, E. Ferentinos, G. Charalambidis, K. Ladomenou, V. Nikolaou, S. Biswas, G. D. Sharma and
A. G. Coutsolelos, RSC Adv., 2016, 6, 22187; (h) U. Meinhardt, F. Lodermeyer, T. A. Schaub, A. Kunzmann, P. O. Dral, A. C. Sale, F. Hampel, D. M. Guldi, R. D. Costa and M. Kivala, RSC Adv., 2016, 6, 67372.

25 H. He, A. Gurung and L. Si, Chem. Commun., 2012, 48, 5910. 26 (a) A. Fillinger and B. A. Parkinson, J. Electrochem. Soc., 1999, 146, 4559; (b) M. K. Nazeeruddin, P. Péchy, T. Renouard, S. M. Zakeeruddin, R. Humphry-Baker, P. Comte, P. Liska, L. Cevey, E. Costa, V. Shklover, L. Spiccia, G. B. Deacon, C. A. Bignozzi and M. Grätzel, J. Am. Chem. Soc., 2001, 123, 1613; (c) S. Ushiroda, N. Ruzycki, Y. Lu, M. T. Spitler and B. A. Parkinson, J. Am. Chem. Soc., 2005, 127, 5158; (d) K.-J. Hwang, W.-G. Shim, S.-H. Jung, S.-J. Yoo and J.-W. Lee, Appl. Surf. Sci., 2010, 256, 5428; (e) C. Y. Lee, C. She, N. C. Jeong and J. T. Hupp, Chem. Commun., 2010, 46, 6090; $(f)$ Y. Sakuragi, X.-F. Wang, H. Miura, M. Matsui and T. Yoshida, J. Photochem. Photobiol., A, 2010, 216, 1; (g) Y. Hara, M. I. Tejedor-Tejedor, K. Lara, D. Lubin, L. J. Brzozowski, D. J. Severseike and M. A. Anderson, Electrochim. Acta, 2011, 56, 8873 . 